DOI: 10.46340/eppd.2020.7.6.26

\author{
Iryna Hioane \\ ORCID ID: https://orcid.org/0000-0001-6923-6001 \\ The State Enterprise "Ukrainian Intellectual Property Institute" (Ukrpatent), \\ Ukraine
}

\title{
FORMATION OF PARAMETERS \\ OF POLITICAL CHOICE IN THE CONTEXT OF DEVELOPMENT OF SOCIAL AND HUMANITARIAN EDUCATION
}

\author{
Ірина Гіоане \\ (УКРПАТЕНТ), Україна

\section{ФОРМУВАННЯ ПАРАМЕТРІВ ПОЛІТИЧНОГО ВИБОРУ В КОНТЕКСТІ РОЗВИТКУ СОЦАЛЬНО-ГУМАНІТАРНОЇ ОСВІТИ}

Державне підприємство «Український інститут інтелектуальної власності»

The article is devoted to the study of the problem of forming political choices in a modern democratic society. It is noted that the leading factors of political choice are internal cultural values and stereotypes formed in the minds of citizens, as well as external influences of the social environment. To a large extent, the parameters of political choice are formed by the means of education, which should instill the knowledge and skills necessary to create a conscious civic position, the ability to act as a competent subject of political activity in special programs. The special urgency of development and improvement of political and legal education, modernization of methods and means of training is defined in modern conditions of contradictory dynamics of social processes.

Keywords: political choice, political culture, socio-humanitarian education, civic position, sociopolitical competencies.

Постановка проблеми. Формування політичного вибору громадян в демократичному суспільстві залежить від внутрішньої позиції суб'єкта політичного мислення та дії, а також зовнішніх впливів конкретної соціально-політичної ситуації, культурних традицій та суспільного досвіду. Серед механізмів формування політичного вибору центральну роль відіграють політична освіта та виховання необхідних навичок та умінь. Політико-правова культура суспільства потребує систематичного раціонального формування, стимулювання та позитивного соціального розвитку. Е. Тоффлер, вивчаючи значення сучасної освіти, наголошував на необхідності формування індивідуальних якостей прийняття рішень у складних ситуаціях нестабільності та високої динамічності соціально-політичних процесів. Він визначав: «Завдання освіти зрозуміле: насамперед підвищити здатність індивіда долати труднощі, тобто здатність швидко та економно адаптуватися до безперервно мінливих умов. I чим стрімкіша швидкість змін, тим більше уваги потрібно приділяти розпізнаванню моделі майбутніх подій» ${ }^{1}$.

Аналіз останніх досліджень та публікацій. Сутність політичного вибору більшістю вчених розглядається в контексті теорій функціонування та процедур прямої і представницької демократії (Д. Блек, Дж. Б’юкенен, Е. Даунс, К. Ерроу, Х. Кісінджер, Дж. Найт, Д. Норт, Е.Тоффлер та ін.). В українській політичній науці аналізу феномену політичного вибору приділяли увагу такі дослідники, як В. Бабкін, О. Бабкіна, В. Білоус, В. Буткевич, В. Бушанський, М. Головатий, Є. Головаха, В. Горбатенко, Г. Зеленько, Л. Кочубей, О. Новакова, П. Шляхтун, В. Якушик та ін.

\footnotetext{
${ }^{1}$ Тоффлер, Э. (2002). Шок будущего. Москва: АСТ, 436.
} 
Формування принципів вищої освіти в європейських країнах та сучасний розвиток Болонського процесу стали предметом вивчення $\quad$ В. Андреєва, I. Бабина, О. Дубасенюк, Л. Лук'янової, Ю. Рашкевича, А. Сбруєвої та ін. Разом з тим, подальшого дослідження потребують проблеми ефективності вищої освіти в контексті формування знань та навичок успішного функціонування в ситуації сучасних викликів пришвидшеної динаміки розвитку в усіх сферах життя людини.

Метою дослідження $\epsilon$ обгрунтування ролі соціально-гуманітарної освіти як чинника формування параметрів політичного вибору в демократичному суспільстві.

Виклад основного матеріалу. На думку авторів відомої ювілейної доповіді Римського клубу (2018 р.), головним завданням сучасної освіти є формування у молоді «освіченості по відношенню до майбутнього», здатності приймати рішення на основі інтегрального мислення, яке може «сприймати, організовувати, узгоджувати, поєднувати окремі фрагменти та досягати дійсного розуміння основоположної реальності» ${ }^{1}$.

Соціальні науки відіграють провідну роль у формуванні політичних і соціальних компетенцій, що пов'язані зі здатністю брати на себе відповідальність, приймати участь у спільному вирішенні актуальних проблем, у функціонуванні демократичних інститутів, регулювати конфлікти ненасильницьким способом. Вміння соціального та громадського характеру згадуються у переліку iз 8 компетенцій для навчання протягом всього життя європейських еталонних рамок, що визначені відповідною Рекомендацією Європейського Парламенту та Ради (СС) від 18 грудня 2006 року². Ці компетенції грунтуються на вміннях громадського характеру, які регулюють усі форми ефективної та конструктивної участі людини у соціально-політичній діяльності плюралістичного суспільства. Основними засадами вмінь громадського характеру виступають наступні:

- знання принципів демократії, справедливості, рівності, громадянства та громадянських прав. Здатність усвідомлювати як актуальні події, так і тенденції національної, європейської та всесвітньої історії;

- обізнаність у ідеологічно-ціннісних основах діяльності провідних політичних партій, рухів та лідерів;

- здатність приймати активну участь в комунікації та партнерській співпраці іншими суб’єктами у сфері прийняття і реалізації рішень державного чи місцевого характеру.

Отже, провідна роль у забезпеченні гносеологічного блоку політико-правової культури відіграє навчальний процес, винятково важливе значення в якому відіграють суспільні науки, що надають студентам загальнополітичні знання про суть політики й політичних норм, права, обов'язки громадян, про політичні процеси, які відбуваються в державі та у світі, сприяють формуванню громадських чеснот та якостей ${ }^{3}$. Разом $з$ тим, варто відзначити, що не завжди усвідомлюється необхідність вивчення цих дисциплін у системі вищої освіти. Зокрема, зазначає О. Лещенко, причини негативного ставлення до вивчення гуманітарних дисциплін у вищих технічних навчальних закладах виявляють ті проблеми, які, власне, і заважають діалектичній єдності природничо-наукового і гуманітарного знання: слабкість матеріально-технічної бази викладання гуманітарних предметів; невідповідність навчальних програм потребам професійної діяльності; невиправдане зменшення кількості годин; перевага спеціалістів вузькопрофільного орієнтування; домінування простих тестових завдань на іспитах та ін. ${ }^{4}$

На дещо інші проблеми соціально-управлінського характеру вказує I. Карпінський. На його думку, негативне відношення до гуманітарної підготовки студентів можна пояснити трьома головними причинами: «По-перше, це застаріле управління вищою освітою, без змін, неефективне, громіздке, бюрократично-свавільне, корумповане, малоініціативне чи зовсім лякливе до ініціатив; подруге, охлократичні тенденції в політичній свідомості значної частини адміністративних кадрів, політиків та простих громадян, некомпетентність, презирливе ставлення до знань (насамперед гуманітарних), досвіду світової цивілізації, антиінтелектуалізм усфері гуманітарних знань

\footnotetext{
${ }^{1}$ Weizsaecker, E., Wijkman, A. (2018). Come On! Capitalism, Short-termism, Population and the Destruction of the Planet. Springer, 220.

${ }^{2}$ Рекомендація 2006/962/СС про основні компетениії для навчання протягом усього життя, 2006 (Європейський Парламент та Ради ЄС). Офіиійний сайт Верховної Ради України <http://zakon0.rada.gov.ua/laws/show/994_975> (2020, вересень, 10).

${ }^{3}$ Грицай, С. М. (2015). Формування політичної культури майбутніх вчителів у процесі навчання. Засоби навчальної та науково-дослідної роботи, 44, 59.

4 Лещенко, О. (2013). Роль дисциплін гуманітарного циклу у формування професійної компетентності майбутніх інженерів. Педагогіка і психологія професійної освіти, 3, 86.
} 
в українському суспільстві; по-третє, зворотна реакція деяких викладачів технічних вишів на особливе становище суспільних наук в минулому. Тому, нині гуманітарні кафедри знову стоять перед завданням доводити свою необхідність» ${ }^{1}$.

Через окреслені вище причини, та інколи через незадовільний рівень викладання гуманітарних дисциплін, знаходить підтримку ідея скорочення їх обсягу у підготовці фахівців. Головним аргументом на ії користь зазвичай $є$ посилання на європейський досвід. Характеризуючи загальну ситуацію з вивченням соціальних дисциплін в Україні та у Європі, варто відзначити, що дійсно питома вага гуманітарних дисциплін у навчальних планах непрофільних європейських університетів менша, ніж в українських.

Зокрема, аналіз бакалаврських освітніх програм підготовки інженерів-технологів харчової промисловості в європейських та українських навчальних закладах, здійснений Г. Чередніченко та О. Климовою, демонструє домінування спеціальних дисциплін та незначну долю загальних гуманітарних. Наприклад, у чотирирічній бакалаврській програма Лодзького університету (Польща) спеціальні дисципліни становлять більшу частину навчальної програми: $65 \%$, збільшуються з $30 \%$ на першому році до $76 \%$ на другому і $92 \%$ на третьому та четвертому роках. Дисципліни профілю економіки становлять $8 \%$ на першому році навчання та 9\% на другому. Фізико-математичні предмети скорочуються $347 \%$ на першому році до 5\% на другому. Гуманітарні дисципліни становлять 9\% на першому та другому роках навчання і $8 \%$ на третьому та четвертому ${ }^{2}$. У інших провідних університетах даного профілю спеціальні дисципліни складають понад $80 \%$ навчальної програми, а серед дисциплін, які з певною долею умовності можна віднести до гуманітарних, згадується лише економіка і менеджмент, питома вага яких складає 2-4\%. Зокрема, у межах трирічної бакалаврської програми Вагенінгенського університету (Нідерланди) дисципліни профілю економіка та менеджмент становлять $2 \%$ на першому році навчання та $10 \%$ на третьому (загалом $4 \%$ ), а у межах чотирирічної бакалаврської програми Дублінського університету (Ірландія) економіку і менеджмент викладають лише на четвертому році навчання (8\%), що становить лише $2 \%$ від всього навчального плану. Для порівняння у Національному університеті харчових технологій (Україна), спеціальні дисципліни складають $56 \%$, а гуманітарні - $15 \%{ }^{3}$. Це дало підстави для висновку дослідників про необхідність посилення спеціальної підготовки у вітчизняних вишах за рахунок гуманітарної складової.

Автори монографії «Оптимізація циклу соціально-гуманітарних дисциплін у вищій освіті України в контексті євроінтеграції», досліджуючи специфіку американської освіти, також відзначають доволі високий рівень профільної орієнтації американської вищої школи, домінування в навчальних планах тих дисциплін, що формують фахове знання, фахове мислення і відповідну компетентність. В той же час, здійснене авторами дослідження підготовки майбутніх бакалаврів з електротехніки в американських університетах, демонструє, що гуманітарна підготовка відчутно більша, ніж у попередніх європейських прикладах. Увесь обсяг програми за чотири роки 135 модулів, з яких 24 припадає на соціальні та гуманітарні предмети (майже $18 \%)^{4}$.

Найбільшою увагою користується формування глибоких знань по історії США та навичок успішного спілкування і роботи в гетерогенній спільноті. 3 позиції формування навичок політичного вибору дуже корисними є характерні для програм американських коледжів та мало представлені в Свропі комунікативні дисципліни - публічний виступ, дискусія в малих групах, що спрямовані на розвиток самостійного критичного мислення. У Франції, як й у більшості інших континентальних європейських держав, зазначають автори згадуваної вище монографії, спостерігається переважна орієнтація на професійну й спеціалізовану підготовку студента й не передбачається предметне вивчення соціально-гуманітарних дисциплін. У той же час, навчальні програми містять своєрідний модуль «Самовираження i спілкування» («Expression et

\footnotetext{
${ }^{1}$ Карпінський, I. Ю. (2010). Роль гуманітарних дисциплін в формуванні сучасного інженера. VIII МНПК Гуманізм та освіта. <http://conf.vntu.edu.ua/humed/2010/txt/karpinsky.php/> (2020, червень, 15).

2 Чередніченко, Г. А., Климова . О.В. (2016). Забезпечення якості освітніх програм підготовки інженерівтехнологів харчової галузі в контексті процесів глобалізації і євроінтеграції. Педагогіка формування творчої особистості у вищій і загальноосвітній школах, 51 (104), 309.

3 Чередніченко, Г.А., Климова, О.В. (2016). Забезпечення якості освітніх програм підготовки інженерівтехнологів харчової галузі в контексті процесів глобалізації і євроінтеграції. Педагогіка формування творчої особистості у вищій $і$ загальноосвітній школах, 51 (104), 311.

${ }^{4}$ Онкович, Г. В. (ред.) (2014). Оптимізація цииклу соціально-гуманітарних дисциплін у вищій освіті України в контексті євроінтеграції. Київ: Інститут вищої освіти НАПН України, 27-28.
} 
communication»). Модуль складається з курсів «Іноземна мова», «Публічно-ділове спілкування», «Риторика», «Ділове листування», «Конфліктологія» тощо ${ }^{1}$.

Більш глибоке дослідження визначеної проблеми показує, що суто кількісні показники не свідчать про реальний вплив соціально-гуманітарної освіти у західних країнах. Дійсно, на сучасному етапі відбувається активне переосмислення ролі соціально-гуманітарних наук в розвинених демократичних країнах. Певна зміна освітніх пріоритетів пов'язана з широким запровадженням інформаційно-комунікативних технологій в процеси виробництва. Як зазначає I. Карпінський, «якщо раніше від технічного працівника з вищою освітою вимагали лише високу кваліфікацію для того, щоб він вчасно міг розпізнати і ліквідувати різні збої на виробництві, то нині це в змозі зробити технік чи механік з допомогою різних технічних засобів, а від технічних спеціалістів з вищою освітою вимагають передусім творчості» ${ }^{2}$. Втім наведені вище висловлювання характеризують переважно ситуацію у США, де в межах чиказької моделі коледжу розвивалася традиція глибокого застосування соціально-гуманітарних курсів в процесі підготовки майбутнього фахівця, його успішності в конкурентних змаганнях з іншими учасниками ринкових відносин ${ }^{3}$.

Європейська освітня практика відрізняється значною увагою до іноземних мов, як частини професійної підготовки, та другорядністю решти гуманітарних дисциплін, які, зазвичай, вивчаються факультативно. Це пояснюється тривалістю середньої освіти (12-14 років) і перенесенням соціальногуманітарних дисциплін на рівень старшої школи (3-4 роки). Саме на цьому етапі приділяється велика увага формуванню необхідних для суспільно-політичного життя громадянських компетенцій. До того ж, практика організації освітнього процесу в західних країн передумовлює більш чітке розрізнення соціальних та гуманітарних наук. Перші мають більшу вагу та включають в себе політологію, соціологію, інколи історію та деякі інші ${ }^{4}$. Серед них важлива роль 3 точки зору формування політикоправової культури особистості відводиться курсу політичних наук.

В даному контексті нелогічним виглядає ініціатива Міністерства освіти та науки України з 2009-2010 навчального року віднести курси політології, соціології, права до категорії вибіркових 5 . На підставі такого рішення та під впливом загальної демографічної ситуації у багатьох вищих навчальних закладах, особливо технічного напрямку, відбувається або вилучення політології 3 навчальних програм або, суттєве скорочення годин на їі вивчення. Паралельно відповідне питання стало предметом обговорення фахівців і громадськості.

Як зазначає О. Рафальський, «варто пам’ятати, що фахівці, яких ми випускаємо, мають бути творцями суспільної атмосфери, а без основ політичного знання вони навряд чи зможуть виконувати функцію акумулювання, осмислення інтересів своїх професійних страт і донесення цих інтересів і потреб до органів державної влади та управління, до політичного класу» ${ }^{6}$.

Дійсно, політична наука забезпечує найвищу форму поваги до гідності особистості, оскільки надає людині можливість більш вільно діяти та більш усвідомлено обирати позицію в боротьбі політичних сил за владу, за вплив на свідомість населення ${ }^{7}$. У вилученні політології із навчального процесу можна побачити і відверто маніпулятивний контекст. Зокрема, зазначають А. Сіленко та Л. Кормич, «коли громадяни не мають достатніх знань про політику, суспільство й державу, владі набагато простіше уникати контролю з боку громадянського суспільства. Так само, як і простіше здобувати потрібну підтримку від народу під час опитувань, виборів, референдумів завдяки некомпетентності пересічних респондентів у конкретних політичних питаннях» ${ }^{8}$.

\footnotetext{
${ }^{1}$ Там само, 28-29.

${ }^{2}$ Карпінський, I. Ю. (2010). Роль гуманітарних дисциплін в формуванні сучасного інженера. VIII МНПК

Гуманізм та освіта. <http://conf.vntu.edu.ua/humed/2010/txt/karpinsky.php/> (2020, червень, 15).

${ }^{3}$ Онкович, Г. В. (ред.) (2014). Оптимізація цүиклу соціально-гуманітарних дисциплін у вищій освіті України в контексті євроінтеграції. Київ: Інститут вищої освіти НАПН України, 29.

${ }^{4}$ Шевчук, Т. (2016). Роль гуманітарної підготовки в технічному ВНЗ. Науковий Вісник МНУ

імені В. О. Сухомлинського. Педагогічні науки, 1 (52), 71.

${ }^{5}$ Сіленко, А. (2010). Політологія та соціологія в освітньому процесі України: Болонський процес чи відступ від демократії? Віче, 13, 31 .

${ }^{6}$ Рафальський , О. О. (2016). Суспільна функція політичної науки і їі роль на сучасному етапі розвитку України. Вісник НАН Украӥни, 5, 45.

${ }^{7}$ Грицай, С. М. (2015). Формування політичної культури майбутніх вчителів у процесі навчання. Засоби навчальної та науково-дослідної роботи, 44, 58.

${ }^{8}$ Сіленко, А. (2010). Політологія та соціологія в освітньому процесі України: Болонський процес чи відступ від демократії? Віче, 13, 31.
} 
Тому на теперішньому етапі варто зосередитись на системі політико - правової освіти, розглянути суперечності та окреслити засоби їх подолання шляхом модернізації навчального процесу. Цілісна структура викладання політико-правових дисциплін має включати матеріал громадськополітичної спрямованості, володіти системністю, цілісністю, логічністю, емоційністю, а відтак для оптимізації змісту і структури навчальних дисциплін циклу доцільно вжити заходів щодо розробляння і зміни державних освітніх стандартів, подбати про осучаснення методичних засад. У процесі вивчення відповідних дисциплін слід використовувати всі наявні в педагогіці форми і методи навчання, особливо - новітні, адже вивчення політико-правових дисциплін буде значно ефективнішим, якщо і під час самостійної роботи студенти і викладачі використовуватимуть безмежні можливості мережі Інтернет, освітні сайти, електронні підручники, інтерактивні програми тощо ${ }^{1}$.

Модернізація навчального процесу при цьому передбачає:

- формування навичок самостійного пошуку та засвоєння знань, творчого, системного мислення;

- застосування індивідуальних підходів до освіти конкретної людини з урахуванням іiі власного когнітивно-креативного потенціалу;

- реалізацію концепції безперервної освіти протягом усього життя людини для забезпечення іiі задіяності на сучасному ринку праці;

- формування навичок активної участі та комунікативної взаємодії з партнерами по вирішенню суспільно-політичних проблем;

- гуманітаризацію вищої освіти, що дозволяє розкрити творчій потенціал особистості, розробляти інноваційні шляхи розвитку соціуму².

Висновки. Політична освіченість надзвичайно важлива в ситуації перманентного політичного вибору, що характеризує функціонування демократичного суспільства. Ефективність політичного управління в умовах конкуренції політичних акторів залежить від здатності забезпечити єдність держави на грунті активної громадянської позиції, яка побудована на усвідомленні провідної ролі громадянського суспільства в прийнятті рішень, толерантності та рівноправній комунікативній взаємодії. Важливими є уміння критично та раціонально усвідомлювати інформаційні потоки, протистояти маніпулятивних впливам та відвертій пропаганді, через політичну участь вирішувати актуальні проблеми як окремої громади, так і країни в цілому.

\section{References:}

1. Hrytsai, S.M. (2015). Formuvannia politychnoi kultury maibutnikh vchyteliv u protsesi navchannia [Formation of political culture of future teachers in the learning process]. Zasoby navchalnoi ta naukovo-doslidnoi roboty [Means of educational and research work], 44, 54-61. [in Ukrainian].

2. Leshchenko, O. (2013). Rol dystsyplin humanitarnoho tsyklu u formuvanni profesiinoi kompetentnosti maibutnikh inzheneriv [The role of disciplines of the humanities in the formation of professional competence of future engineers]. Pedahohika i psykholohiia profesiinoi osvity [Pedagogy and psychology of vocational education], 3, 84-90. [in Ukrainian].

3. Karpinskyi, I.Yu. (2010). Rol humanitarnykh dystsyplin v formuvanni suchasnoho inzhenera [The role of the humanities in the formation of the modern engineer]. VIII Mizhnarodna naukovo-praktychna konferentsiia Humanizm ta osvita [VIII International Scientific and Practical Conference. Humanism and Education]. <http://conf.vntu.edu.ua/humed/2010/txt/karpinsky.php/> (2020, June, 15). [in Ukrainian].

4. Novakova, O.V. (2020). Chynnyky vdoskonalennia navchalno-metodychnoho zabezpechennia pidhotovky suchasnykh politolohiv u haluzi vyshchoi osvity [Factors for improving the educational and methodological support for the training of modern political scientists in the field of higher education]. Naukovyi chasopys NPU imeni MP Drahomanova. Seriia 22: Politychni nauky ta metodyka vykladannia sotsialno - politychnykh dystsyplin [Scientific journal of NPU named after MP Drahomanov. Series 22: Political Science and Methods of Teaching Socio - Political Disciplines], 27, 19-25. [in Ukrainian].

5. Onkovych, H.V. (ed.) (2014). Optymizatsiia tsyklu sotsialno-humanitarnykh dystsyplin u vyshchii osviti Ukrainy $v$ konteksti yevrointehratsii: monohrafiia [Optimization of the cycle of social and humanitarian disciplines in higher education of Ukraine in the context of European integration: monograph]. Kyiv: Instytut vyshchoi osvity NAPN Ukrainy. [in Ukrainian].

\footnotetext{
${ }^{1}$ Онкович, Г.В. (ред.) (2014). Оптимізаџฺія цฺиклу соціально-гуманітарних дисцииплін у вищій освіті України в контексті євроінтеграції. Київ: Інститут вищої освіти НАПН України, 9.

${ }^{2}$ Новакова, О.В. (2020). Чинники вдосконалення навчально-методичного забезпечення підготовки сучасних політологів у галузі вищої освіти. Науковий часопис НПУ імені МП Драгоманова. Серія 22: Політичні науки та методика викладання соціально - політичних дисциилін, 27, 23.
} 
6. Rafalskyi, O.O. (2016). Suspilna funktsiia politychnoi nauky i yii rol na suchasnomu etapi rozvytku Ukrainy [The social function of political science and its role at the present stage of development of Ukraine]. Visnyk NAN Ukrainy [Bulletin of the NAS of Ukraine], 5, 44-46. [in Ukrainian].

7. Rekomendatsiya 2006/962/YES pro osnovni kompetentsiyi dlya navchannya protyahom us'oho zhyttya, 2006 (Yevropeyskyy Parlament ta Rady YES) [Recommendation 2006/962 / EU on core competences for lifelong learning ", 2006 (European Parliament and Council of the EU)]. Ofitsiynyy sayt Verkhovnoyi Rady Ukrayiny [Official site of the Verkhovna Rada of Ukraine] <http://zakon0.rada.gov.ua/laws/show/994_975> (2020, September, 10). [in Ukrainian].

8. Cilenko, A. (2010). Politolohiia ta sotsiolohiia v osvitnomu protsesi Ukrainy: Bolonskyi protses chy vidstup vid demokratii? [Political Science and Sociology in Ukraine's Educational Process: The Bologna Process or a Deviation from Democracy?]. Viche [Veche], 13, 31-32. [in Ukrainian].

9. Toffler, Je. (2002). Shok budushhego [Shock of the future]. Moscow: AST. [in Russian].

10. Cherednichenko, H. A., Klymova O. V. (2016). Zabezpechennia yakosti osvitnikh prohram pidhotovky inzhenerivtekhnolohiv kharchovoi haluzi v konteksti protsesiv hlobalizatsii i yevrointehratsii [Ensuring the quality of educational programs for the training of food engineers in the context of globalization and European integration]. Pedahohika formuvannia tvorchoi osobystosti u vyshchii $i$ zahalnoosvitnii shkolakh [Pedagogy of formation of creative personality in higher and general education schools], 51 (104), 307-314. [in Ukrainian].

11. Shevchuk, T. (2016). Rol humanitarnoi pidhotovky v tekhnichnomu VNZ [The role of humanitarian training in technical universities]. Naukovyi Visnyk MNU imeni V. O. Sukhomlynskoho. Pedahohichni nauky [Scientific Bulletin of VO Sukhomlinsky MNU. Pedagogical sciences], 1 (52), 70-75. [in Ukrainian].

12. Weizsaecker, E., Wijkman, A. (2018). Come On! Capitalism, Short-termism, Population and the Destruction of the Planet. Springer. [in English]. 